\title{
From the Machete to the Microscope: Dennis Stevenson, Plant Morphologist
}

\author{
Paula J. Rudall ${ }^{1,3} \cdot$ Chelsea D. Specht $^{2}$ \\ ${ }^{1}$ Royal Botanic Gardens, Kew, Richmond, Surrey TW9 3AB, UK \\ ${ }^{2}$ School of Integrative Plant Science, Section of Plant Biology and the L.H. Bailey Hortorium, Cornell \\ University, Ithaca, NY 14853, USA \\ ${ }^{3}$ Author for Correspondence; e-mail: p.rudall@kew.org \\ Published online: 26 April 2021 \\ (C) The Author(s) 2021
}

\begin{abstract}
To mark the commencement of Dennis Stevenson's status as Senior Curator Emeritus at New York Botanical Garden, we present a brief and subjective overview of his academic achievements to date. We highlight his deep and scholarly background in plant morphology, his adherence to cladistic methodologies for testing hypotheses of organismal relationships, especially in cycads and monocots, and his inspirational influence on students and colleagues within the botanical community.
\end{abstract}

Keywords Dennis Wm. Stevenson · Plant morphology · Cycads · Monocots · Cladistics

\section{Introduction}

Dennis Stevenson is a pivotal player in a long tradition of plant morphology; yet at the same time he is a genuinely unique scientist and scholar, whose approach to his diverse research projects remains steadfastly unconventional. Fundamentally an empiricist, his curious, open-minded and highly social modus operandi has been exceptionally catalytic, sparking the interest of a broad spectrum of researchers in his wide-ranging initiatives. Much to his credit, he remains a hands-on scientist who continues to interact with his wide circle of collaborators and friends, providing both big-picture oversight and ideas as well as detailed and nuanced information concerning plant morphology, physiology, anatomy, systematics, evolution, and development to a large number of successful research collaborations and initiatives. Dennis often presents himself as a lovable reprobate, but in fact there is nobody more committed and principled with respect to his own academic sphere. In this article, we present our unashamedly subjective impression of his research career to date, to mark his latest career transition to Senior Curator Emeritus at New York Botanical Garden (NYBG). This appointment, which allows him to focus more intently on research, accompanies his ongoing adjunct positions at Yale University (Professor of Forestry since 1996), Columbia University (Professor of Biology since 1998), Cornell University (Professor of Plant Biology since 2000), and the American Museum of Natural History (Research Associate since 2016). 

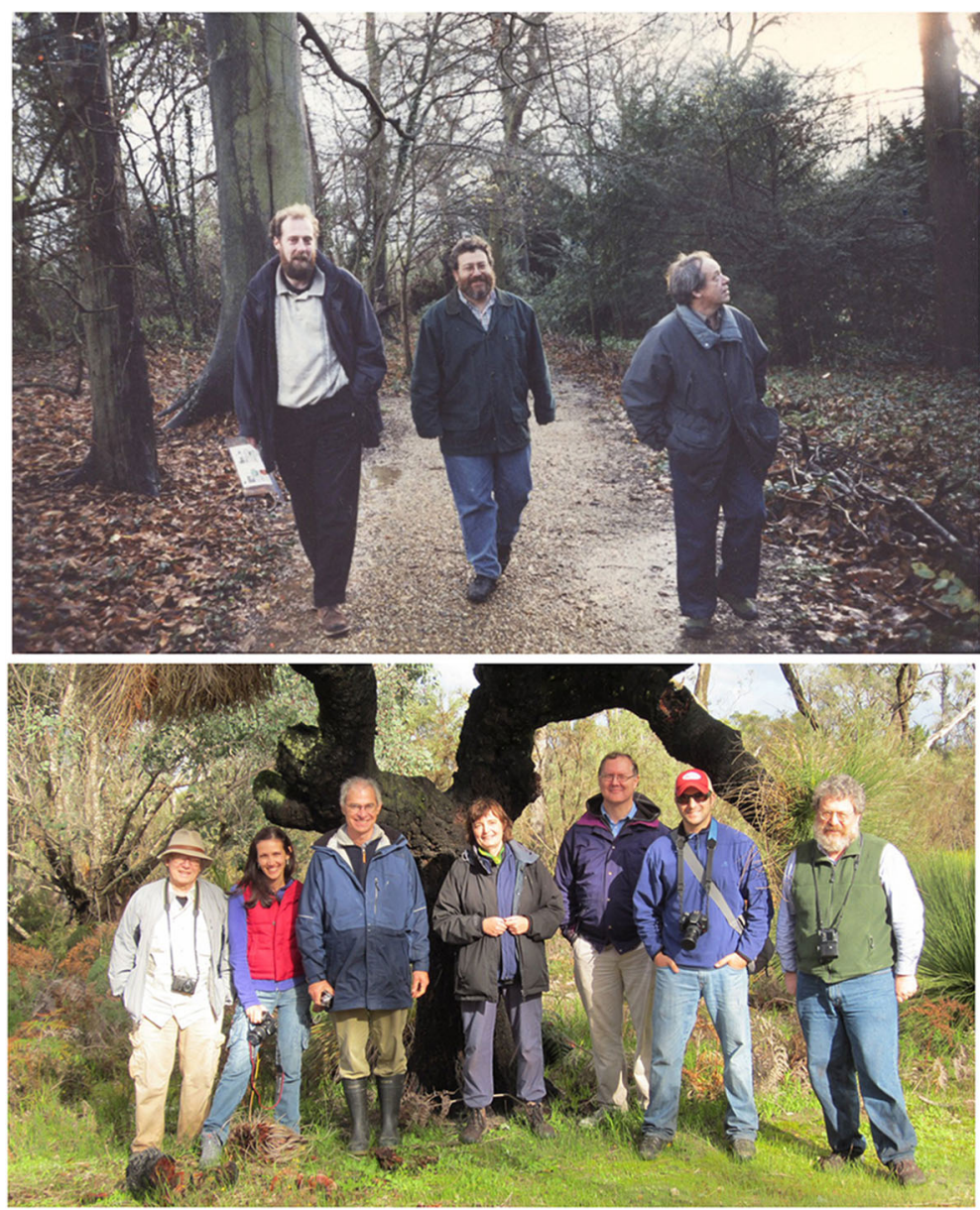

Fig. 1 (Top) In Darwin's footsteps (2000): Dennis walking the Sandwalk trail at Down House with Richard Bateman (left) and Jerry Davis (center). (Bottom) Field botanist (2011): Dennis in Western Australia with (L to R) Dennis, Marcela Thadeo, Terry Macfarlane, Paula Rudall, John Conran, Craig Barrett, Jerry Davis

\section{Early Influences}

Dennis Stevenson's impressive list of early influences in plant morphology include his Master's advisor Richard Popham at Ohio State University, his PhD advisor Ernest Gifford at UC Davis, cycad specialist Knut Norstog, fellow structural botanist and early collaborator Rudolf Schmid, and the plant morphologist Barry Tomlinson, who Dennis first worked with at Fairchild Tropical Garden as a Harvard postdoctoral fellow (19751976). During his studies, Dennis was also inspired by the work of Shirley Tucker, who acted as an unofficial mentor during his doctoral studies and introduced him to the breadth and depth of the botanical community. Dennis' earliest work was centered on structural botany, in particular focusing on unique ontological and anatomical features of ferns, lycophytes and mosses with occasional forays into monocots when a particularly intriguing theory needed anatomical attention (e.g., phyllode theory and leaf ontogeny in Sansevieria). Dennis demonstrated mastery in applying his skills and 
prolific knowledge to questions that spanned plant diversity, a quality that is prevalent throughout his career. Going beyond his own microscope, his career includes continual advocacy for the value of collection-based field and laboratory research. Often this advocacy was ahead of its time: in 1976, Dennis collaborated with Rudolf Schmid to argue for the formation of a new journal (Arberia, named for Agnes Arber: Schmid and Stevenson 1975, 1976) that would highlight advances in structural botany and link them to functional traits - value that was perhaps most profoundly recognized with the rise of evo-devo studies in the late 1990s.

Following his work at Fairchild, Dennis undertook a second postdoctoral tenure as a NATO Fellow at the Royal Botanic Gardens, Kew, United Kingdom (1976-1977), where one of us (PJR) was a newly-appointed doctoral student. Dennis' deep knowledge of plant morphology and anatomy, coupled with his immense energy, generosity and enthusiasm were inspirational, not only to an impressionable young student but also to many others at Kew. In a short time, Dennis broadened the scope of Kew's research, introduced new lab methods, and even helped to establish a new Electron Microscopy lab with Simon Owens, who later became Curator of the Kew Herbarium. Dennis has always loved off-the-wall debate; he was constantly forming new botanical connections and liaisons, many of which remain important to him to this day. Together we explored not only Kew's extensive living collections, but also the exciting innovations in cladistic methodology that were being applied to botanical studies, especially at the Natural History Museum in London by Chris Humphries, Colin Patterson and their colleagues. At the time, such methods were often regarded as dangerously radical by the botanical establishment, an attitude further encouraged by the fact that many of the conceptual innovations were devised in local pubs.

\section{Back in the USA}

Having completed his NATO fellowship at Kew, Dennis returned first to Fairchild, then became Assistant Professor of Biology at Barnard College, Columbia University (1980-1987). During this time, he expanded his taxonomic focus to cycads and broadened his studies to reflect systematic implications, ultimately forging the foundation for the next 40 years of research expertise and excellence. He also undertook two short but highly productive visiting Professorships at the University of Naples, Italy $(1985,1986)$, where he worked on the extensive cycad collection in Naples Botanic Garden and established long-lasting research links with fellow cycad researchers Aldo Moretti and Paolo Caputo.

In 1987, Dennis finally accepted a position at New York Botanical Garden that offered him greater stability to explore his scientific potential and broad botanical interests. At NYBG, he progressed through various roles - from Director of the Harding and Lieberman Laboratories, to Director for Graduate Studies, to Vice President for Science and Cullman Senior Curator - each of which enabled him to make a lasting impact on the Garden, its infrastructure and training, and on botanical research in general. Dennis' knowledge of technology and techniques - in the laboratory, greenhouse and field - provided critical insights leading to the visionary architecture of the Pfizer lab while his deep grasp of literature has contributed positively to defining the breadth and depth of NYBG library holdings. 


\section{Training Students and Postdocs}

Coupled with his lively lecturing style and engaging personality, Dennis' unfathomable knowledge about everything botanical has been foundational in stimulating multiple generations of aspiring botanists and bringing them together to create an innovative learning environment at NYBG. The Harding Laboratory, where Dennis made his home in the 1980 s to early 2000 s, became an inspirational place to study plant morphology and systematics and explore advances in cladistic analyses and evo-devo. Anatomical, morphological, chemical, molecular, and ultimately genomic data were combined under his mentorship. Dennis formed working collaborations with faculty at Cornell, CUNY, NYU, and Yale that provided opportunities for students from these graduate programs to take advantage of the collections, knowledge, literature, and botanical community at NYBG. Through his lectures, Dennis instilled a deeper appreciation for botanical diversity and systematics. Key collaborators included several researchers from Cornell University, especially Jerry Davis and Kevin Nixon on cladistics and Maria Alejandra Gandolfo, Bill Crepet, and Karl Niklas on various aspects of structural botany and paleobotany.

Students and postdocs who passed through NYBG during this time and benefited from Dennis' mentorship were variously based at Columbia, Cornell, CUNY, NYU, Stony Brook and Yale; many of them now hold faculty positions of their own. They include Favio Gonzalez, Fabian Michelangeli, Chris Hardy, Nora Barbosa, Chelsea Specht, Eduardo de la Torre, Damon Little, Angelica Cibrian-Jaramillo, Christian Schulz, Flor Chavez, Gwynne Lim, Heather Peckham, Una Smith, Leandro Martínez, Ramona Walls, Brandon Sinn, Marcela Thadeo and Stephanie Schmiege. The breadth of studies of these students and postdocs and their diverse yet successful subsequent career trajectories in botany and plant biology is tribute to the mentorship and the scholarly environment that Dennis provided. In the tradition of NYBG, Dennis has also hosted regular visits from international scholars, colleagues and friends, including the great Soviet-Armenian botanist Armen Tahktajan and his wife Alice and the famous neurologist, naturalist, and best-selling author Oliver Sacks. He has thereby always ensured that students are exposed to ideas, knowledge, and opportunities to form personal and professional connections with some of the greatest scientists and thinkers of our time.

\section{Publications and Research}

Stevenson's academic work - both in published research and associated outreach encompasses both non-seed plants and seed plants, a taxonomic breadth achieved by few other researchers. For several years, Dennis edited the Fiddlehead Forum newsletter of the American Fern Society. One of his earliest listed papers concerns aspects of the anatomy and physiology of a moss, Atrichum undulatum (Stevenson 1974b). Other early studies focus on ferns (e.g., Stevenson 1974a, Stevenson 1976a, 1976b, 1978) and lycophytes (Stevenson 1976c), and he still maintains a strong interest in seed-free plants, with recent studies including development of the lycophyte Selaginella apoda as a model species for genetic and developmental studies (e.g., Schulz et al. 2010) and systematics and comparative phylogenetics of major fern lineages (e.g., Rothfels et al. 

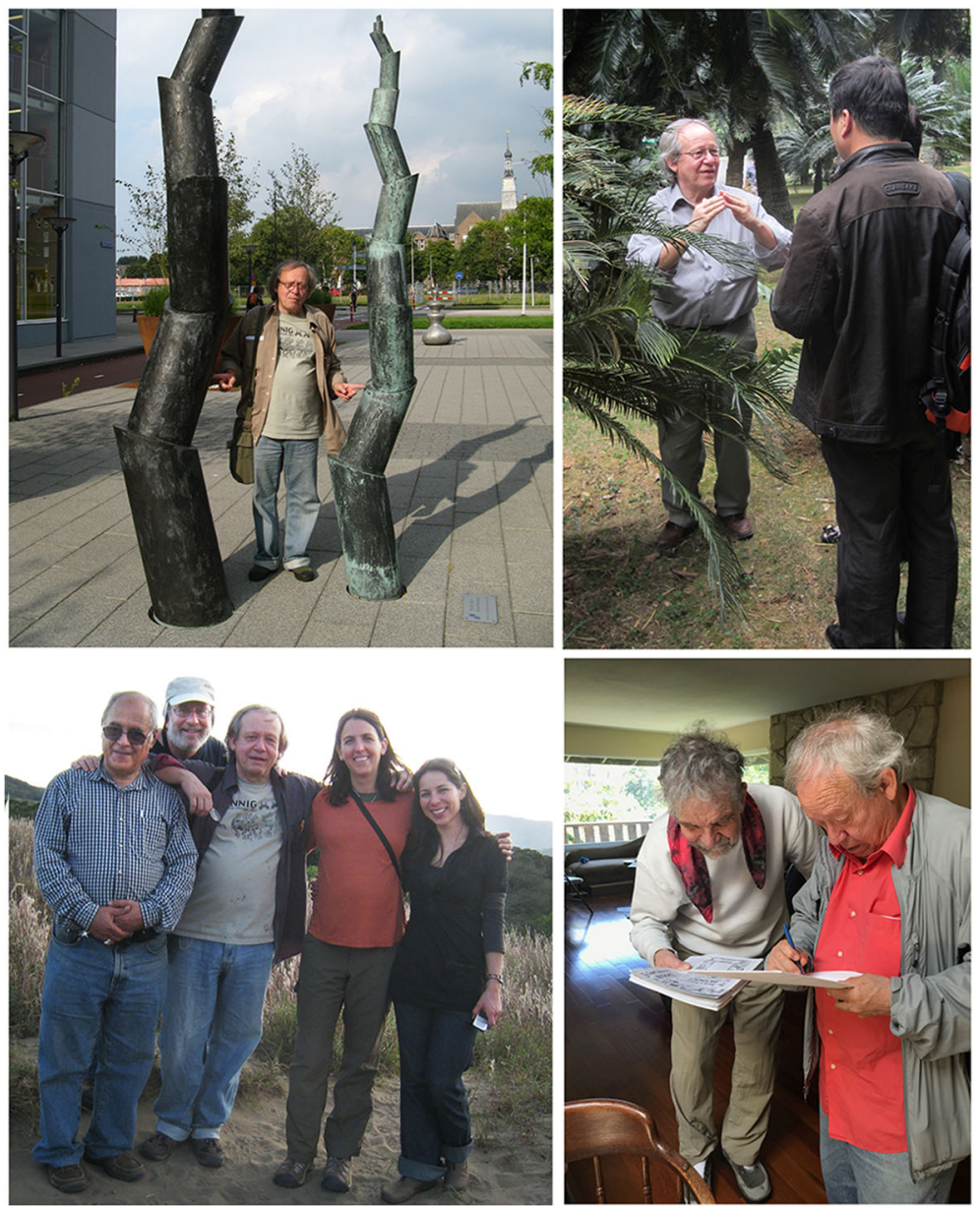

Fig. 2 (Top left) Dennis in Leiden (2009). (Top right) Dennis teaching in China. (Bottom left) Dennis enjoying some time in the field during the Monocots without Borders meeting, Xalapa, Mexico (2008). (Bottom right) Dennis and Rudi Schmidt consulting a map

2015). Continued collaborations on ferns extend to comparative genomics (Sessa et al. 2014), insights into the evolutionary history of key physiological compounds ( $\mathrm{Li}$ et al. $2015 \mathrm{a}, \mathrm{b}$ ) and the developmental influence of gene family diversification (Vasco et al. 2016).

Dennis is probably best known for his work on gymnosperms in general and in particular cycads, a group for which he is well-known as both a field biologist and a research scientist (Nazor and Salzman 2016). Indeed, he has examined almost every species of cycad in its natural habitat. He has been active in the international cycad conference series since their inception in 1987 and co-edited the proceedings volumes of subsequent cycad conferences (Stevenson and Norstog 1993; Vovides et al. 2007; Stevenson et al. 2012; Li et al. 2019). His formal classification of the extant cycads (Stevenson 1992) was a pivotal publication that laid the foundation for subsequent studies investigating systematics and trait diversification across the order, and through his broad knowledge - from anatomy, morphology and natural history to taxonomy, 
systematics, and trait evolution - he continues to influence cycad researchers around the globe (e.g., Salas-Leiva et al. 2013; Vovides et al. 2016; Clugston et al. 2016; Martínez-Domínguez et al. 2018). He even occasionally dips a toe into the paleobotanical realm (e.g., Dower et al. 2004). Those who have strolled through his extensive pickled plant collection know the story of how he even recreated in the lab a megasporangiate cone resembling the famous fossil cycad Beania gracilis!

Another important strand of the Stevenson oevre concerns monocotyledons. Dennis was an engaging presence at the first international monocot conference that one of us (PJR) co-organised at the Royal Botanic Gardens, Kew, in 1993. His publication in the resulting volume was a remarkable monocot-wide cladistic analysis (Stevenson and Loconte 1995) that prompted considerable debate; Dennis was never one to shy away from controversial publications as a way to stimulate additional research, inquiry, and excitement around a particular research field. Dennis has played a role in almost all the subsequent monocot meetings, which are held at five-yearly intervals. In July 2013, he co-organised the fifth monocot meeting at New York Botanical Garden (Bronx) and the adjacent Fordham University Rose Hill Campus; he also co-edited the resulting volume (Campbell et al. 2017). The New York monocot conference had over 330 participants from 37 countries; its huge success owed a considerable amount to Dennis' commitment and hard work. As with most of his research influences, Dennis' contribution to monocot research has been highly collaborative and includes foundational phylogenetic studies inspiring future research. He was a PI on the large NSF Monocot Tree of Life (MonATOL) grant, a research endeavor that attacked big questions while developing tools, databases, and resources that elevated all monocot research and maintained the highly collaborative and productive monocot community. As per his usual theme, Dennis' work on monocots extends from comparative anatomy and morphology through to comparative genomics and phylogenomics revealing evolutionary trends (e.g., Rudall et al. 1999; Specht and Stevenson 2006; Sajo et al. 2012; Barrett et al. 2013, 2014; Thadeo et al. 2015).

Beyond his fern/cycad/monocot taxonomic foci, Dennis has been a consistent contributor to plant systematics through his innovations in cladistic methodology. He has participated in the annual meetings of the Willi Hennig Society and for several years served as editor of the Society's journal Cladistics. His early phylogenetic papers focused on morphological cladistics; rooted in empiricism and addressing large-scale analyses of several major clades, including monocots and seed plants (Loconte and Stevenson 1990; Nixon et al. 1994; Stevenson and Loconte 1995). These groups continue to form the core of his more recent phylogenetic publications, which include molecular data ranging from few-gene phylogenies to phylogenomics and transcriptomics (e.g., Davis et al. 2004; Givnish et al. 2018; Meerow et al. 2019; Bell et al. 2020).

To mark Dennis Stevenson's 65th birthday in 2008, the annual Botanical Society of America conference hosted a symposium in his honour, entitled "Understanding plant evolution: morphology to molecules". Subsequently his colleagues published a festchrift volume (Ambrose et al. 2012) in Botanical Review, the NYBG journal that Dennis has himself edited for many years. This volume includes papers by some of Dennis' former students and associates on conifers, cycads, several monocot groups, and various aspects of floral and vegetative morphology. It remains a testament to his considerable influence and significance in his field of plant morphology and systematics. Dennis has shown no reduction in motivation and enthusiasm for systematic 
research, and continues to participate in projects that attract high citations while defining the trajectory for excellence in comparative plant biology. We look forward to experiencing his influence on botanical research and scholarship and the botanical community for many years to come.

Acknowledgements We thank Richard Bateman for his helpful comments on the manuscript.

Open Access This article is licensed under a Creative Commons Attribution 4.0 International License, which permits use, sharing, adaptation, distribution and reproduction in any medium or format, as long as you give appropriate credit to the original author(s) and the source, provide a link to the Creative Commons licence, and indicate if changes were made. The images or other third party material in this article are included in the article's Creative Commons licence, unless indicated otherwise in a credit line to the material. If material is not included in the article's Creative Commons licence and your intended use is not permitted by statutory regulation or exceeds the permitted use, you will need to obtain permission directly from the copyright holder. To view a copy of this licence, visit http://creativecommons.org/licenses/by/4.0/.

\section{References}

Ambrose, B.A., K.G. Karol, L.M. Kelly, \& F.A. Michelangeli. (2012). Foreword: a festschrift on the occasion of Dennis Wm. Stevenson's 70th birthday. Botanical Review 78: 307-309.

Barrett, C.F., J.I. Davis, J. Leebens-Mack, J.G. Conran \& D.W. Stevenson. (2013). Plastid genomes and deep relationships among the commelinid monocot angiosperms. Cladistics 29: 65-87.

Barrett, C.F., C.D. Specht, J. Leebens-Mack, D.W. Stevenson, W.B. Zomlefer, \& J.I. Davis. (2014). Resolving ancient radiations: can complete plastid gene sets elucidate deep relationships among the tropical gingers (Zingiberales). Annals of Botany 113: 119-133.

Bell, D., Q. Lin, W.K. Gerelle, S. Joya, Y. Chang, Z.N. Taylor, C.J. Rothfels, A. Larsson, J.C. Villarreal, F.W. Li, L. Pokorny, P. Szövény, B. Crandall-Stotler, L. DeGironimo, S.K. Floyd, D.J. Beerling, M.K. Deyholos, M. von Konrat, S. Ellis, A.J. Shaw, T. Chen, G.K.S. Wong, D.W. Stevenson, J.D. Palmer, \& S.W. Graham. (2020). Organellomic data sets confirm a cryptic consensus on unrooted) land-plant relationships, and provide new insights into bryophyte molecular evolution. American Journal of Botany 107: 91-115.

Campbell, L., J.I. Davis, A.W. Meerow, R.F. Naczi, D.W. Stevenson, \& W.W. Thomas. (2017). Diversity and phylogeny of the monocotyledons. Memoirs of the New York Botanical Garden 118: 1-161.

Clugston, J.A.R., M.P. Griffith, G.J. Kenicer, C.E. Husby, M.A. Calonje, D.W. Stevenson, \& D.P. Little. 2016. Zamia (Zamiaceae) phenology in a phylogenetic context: does in situ reproductive timing correlate with ancestry? Edinburgh Journal of Botany 73: 345-370.

Davis, J.I., D.W. Stevenson, G. Petersen, O. Seberg, L. Campbell, J. Freudenstein, D. Goldman, C. Hardy, F. Michelangeli, M. Simmons, C. Specht, F. Vergara-Silva, \& M. Gandolfo. (2004). A phylogeny of the monocots, as inferred from $r b c L$ and atpA sequence variation, and a comparison of methods for calculating jackknife and bootstrap values. Systematic Botany 29: 467-510.

Dower, B.L., Bateman, R.M., \& Stevenson, D.W. (2004). Systematics, ontogeny, and phylogenetic implications of exceptional anatomically preserved cycadophyte leaves from Bearreraig Bay, Skye, Northwest Scotland. Botanical Review 70: 105-120.

Givnish, T.J., A. Zuluaga, D. Spalink, M. Soto Gomez, V. Lam, J. Saarela, C. Sass,, W. Iles, D. Lima, J. Leebens-Mack, J. Chris Pires, W. Zomlefer, M. Gandolfo, J.I. Davis, D.W. Stevenson, C. dePamphilis, C.D. Specht, S.W. Graham, C.F. Barrett, \& C. Ané. (2018). Monocot plastid phylogenomics, timeline, net rates of species diversification, the power of multi-gene analyses, and a functional model for the origin of monocots. American Journal of Botany 105: 1888-1910.

Li, F.W., M. Melkonian, C.J. Rothfels, J.C. Villarreal, D.W. Stevenson, S.W. Graham. G.K.S Wong, K.M. Pryer, \& S. Mathews. (2015a). Phytochrome diversity in green plants and the origin of canonical plant phytochromes. Nature Communications 6: 7852. 
Li, F.W., C.J. Rothfels, M. Melkonian, J.C. Villarreal, D.W. Stevenson, S.W. Graham. G.K.S Wong, S. Mathews, \& K.M. Pryer. (2015b). The origin and evolution of phototropins. Frontiers in Plant Science 12. doi: https://doi.org/10.3389/fpls.2015.00637

Li, N., D.W. Stevenson, \& P. Griffith. (2019). Cycads 9: Cycad Biology \& Conservation. Memoirs of the New York Botanical Garden 117: 1-608.

Loconte, H., \& D.W. Stevenson. (1990). Cladistics of the Spermatophyta. Brittonia 42: 197-211.

Martínez-Domínguez, L., F. Nicolalde-Morejó, F. Vergara-Silva, \& D.W. Stevenson. (2018). Taxonomic review of Ceratozamia (Zamiaceae) in the Sierra Madre Oriental, Mexico. PhytoKeys 100: 91-124.

Meerow, A., D.E. Salas-Leiva, J. Francisco-Ortega, M.P. Griffith, M. Calonje, D.W. Stevenson, \& K. Nakamura. (2019). Phylogeography and conservation genetics of the Caribbean Zamia clade: an integrated systematic approach with SSRs and single copy nuclear genes. Memoirs of the New York Botanical Garden 117: 278-296.

Nazor, C., \& S. Salzman. (2016). Interview with Dennis Stevenson. The Cycad Newsletter 39: 4-8.

Nixon, K., W. Crepet, D.W. Stevenson, \& E.M. Friis. (1994). A reevaluation of seed plant phylogeny. Annals of the Missouri Botanical Garden 81: 484-533.

Rothfels, C.J., F.W. Li, E.M. Sigel, L. Huiet, A. Larsson, D.O. Burge, M. Ruhsam, M. Deyholos, D.E. Soltis, C.N. Stewart, S.W. Shaw, L. Pokorny, T. Chen, C. dePamphilis, L. DeGironimo, L. Chen, X. Wei, X. Sun, P. Korall, D.W. Stevenson, S.W. Graham, G.K-S. Wong, \& K.M. Pryer. (2015). The evolutionary history of ferns inferred from 25 low-copy nuclear genes. American Journal of Botany 102: 1089-1107.

Rudall, P.J., D.W. Stevenson, \& H. Linder. (1999). Structure and systematics of Hanguana, a monocotyledon of uncertain affinity. Australian Systematic Botany 12: 311-330.

Sajo, M.G., N. Pabón-Mora, J. Jardim, D.W. Stevenson, \& P.J. Rudall. (2012). Homologies of the flower and inflorescence in the early-divergent grass Anomochloa (Poaceae). American Journal of Botany 99: 612-628.

Salas-Leiva, D., A. Meerow, M. Calonje, M Griffith, J. Francisco-Ortega, D.W. Stevenson, K. Nakamura, C. Lewis, \& S. Namoff. (2013). Phylogeny of the cycads based on multiple single copy nuclear genes: congruence of concatenated parsimony, likelihood, and species tree inference methods. Annals of Botany 112: $1263-1278$.

Schmid, R., \& D.W. Stevenson. (1975). Arberia, a proposal for a new journal of structural botany. Taxon 24: 493-494.

Schmid, R., \& D.W. Stevenson. (1976). Agnes Arberia, scientific reductionism, and the need for Arberia. Taxon 25: 501-503.

Schulz, C.J., D.P. Little, D.W. Stevenson, D. Bauer, C. Moloney, \& T. Stutzel. (2010). An overview of the morphology, anatomy, and life cycle of a new model species: the lycophyte Selaginella apoda (L.) Spring. International Journal of Plant Science 171: 693-712.

Sessa, E.B., J.A. Banks, M.S. Barker, J.P. Der, A.M. Duffy, S.W. Graham, M. Hasebe, J. Langdale, F.W. Li, D.B. Marchant, K.M. Pryer, C.J. Rothfels, S.J. Roux, M.L. Salmi, E.M. Sigel, D.E Soltis, P.S Soltis, D.W. Stevenson, \& P.G. Wolf. (2014). Between two fern genomes. GigaScience 3: 15.

Specht, C.D. \& D.W. Stevenson. (2006). A new phylogeny-based generic classification of Costaceae (Zingiberales). Taxon 55: 153-163.

Stevenson, D.W. (1974a). The occurrence of "root gaps" in the rhizome solenostele and leaf trace of Dennstaedtia cicutaria. American Journal of Botany 61: 284-289.

Stevenson, D.W. (1974b). Ultrastructure of the nacreous leptoids (sieve elements) in the polytrichaceous moss Atrichum undulatum. American Journal of Botany 61: 414-421.

Stevenson, D.W. (1976a). Shoot apex organization and ontogeny of the rhizome born roots and their associated gaps in Dennstaedtia cicutaria. American Journal of Botany 63: 673-678.

Stevenson, D.W. (1976b). The cytohistological and cytohistochemical zonation of the shoot apex of Botrychium multifidum. American Journal of Botany 63: 852-856.

Stevenson, D.W. (1976c). Observations on phyllotaxis, stelar morphology, the shoot apex, and gemmae of Lycopodium lucidulum. Journal of the Linnean Society, Botany 71: 81-100.

Stevenson, D.W. (1978). Observations on shoot apices of eusporangiate ferns. Kew Bulletin 33: 279-282.

Stevenson, D.W. (1992). A formal classification of the extant cycads. Brittonia 44: 220-223.

Stevenson, D.W., \& H. Loconte. (1995). A cladistic analysis of monocot families. In: P.J. Rudall, P.J. Cribb, D.F. Cutler, C.J. Humphries (Eds.), Monocotyledons: Systematics and Evolution (pp. 543-578). Royal Botanic Gardens, Kew.

Stevenson, D.W., \& K. Norstog. (1993). The Biology, Structure, and Systematics of the Cycadales. Proceedings of the Second International Conference on Cycad Biology. Milton, Australia.

Stevenson, D.W., R. Osborne, \& A. Taylor Blake. (2012). Proceedings of Cycads 2008. Memoirs of the New York Botanical Garden 106: 1-544. 
Thadeo, M., K.E. Hampilos, \& D.W. Stevenson. (2015). Anatomy and development of fleshy fruits in the monocots. American Journal of Botany 102: 1757-1779.

Vasco, A.T., L. Smalls, S.W. Graham, E.D. Cooper, G.K. Wong, D.W. Stevenson, R.C. Moran, \& B.A. Ambrose. (2016). Challenging the paradigms of leaf evolution: Class III HD-Zips in ferns and lycophytes. New Phytologist 212: 748-758.

Vovides, A., D.W. Stevenson, \& R. Osborne. (2007). Proceedings of Cycads 2005. Memoirs of the New York Botanical Garden 97: 1-648.

Vovides, A., D.W. Stevenson, M.A. Pérez-Farrera, S. López, \& S. Avendaño. (2016). What is Ceratozamia mexicana (Zamiaceae)? Botanical Sciences 94: 419-429. 